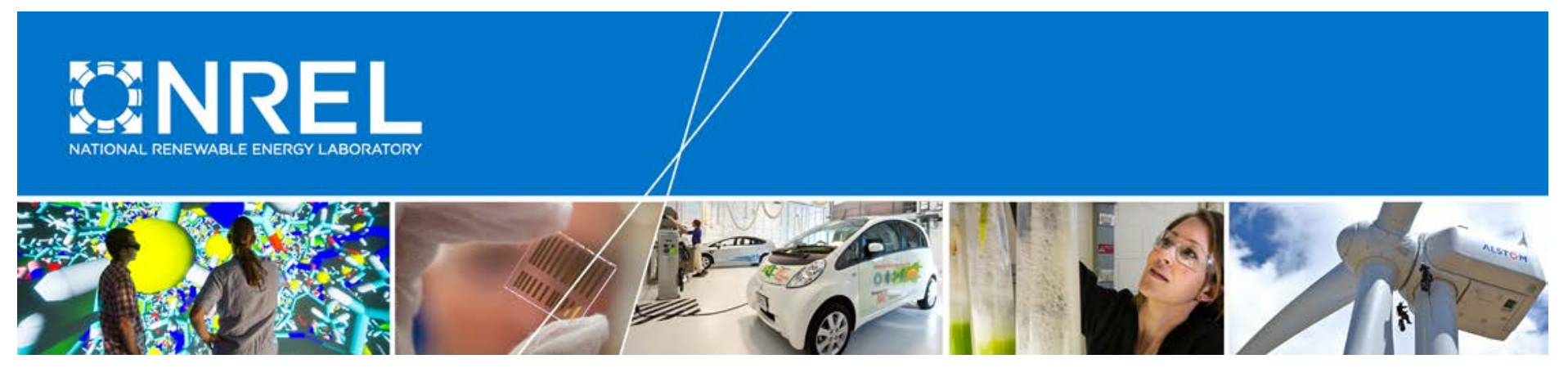

\title{
Cellulosic Biomass Sugars to Advantage Jet Fuel: Catalytic Conversion of Corn Stover to Energy Dense, Low Freeze Point Paraffins and Naphthenes
}

Cooperative Research and Development Final Report

CRADA Number: CRD-12-462

NREL Technical Contact: Rick Elander

NREL is a national laboratory of the U.S. Department of Energy Office of Energy Efficiency \& Renewable Energy Operated by the Alliance for Sustainable Energy, LLC

This report is available at no cost from the National Renewable Energy Laboratory (NREL) at www.nrel.gov/publications.

CRADA Report

NREL/TP-5100-64727

August 2015 


\title{
NOTICE
}

This report was prepared as an account of work sponsored by an agency of the United States government. Neither the United States government nor any agency thereof, nor any of their employees, makes any warranty, express or implied, or assumes any legal liability or responsibility for the accuracy, completeness, or usefulness of any information, apparatus, product, or process disclosed, or represents that its use would not infringe privately owned rights. Reference herein to any specific commercial product, process, or service by trade name, trademark, manufacturer, or otherwise does not necessarily constitute or imply its endorsement, recommendation, or favoring by the United States government or any agency thereof. The views and opinions of authors expressed herein do not necessarily state or reflect those of the United States government or any agency thereof.

This report is available at no cost from the National Renewable Energy Laboratory (NREL) at www.nrel.gov/publications.

Available electronically at SciTech Connect http:/www.osti.gov/scitech

Available for a processing fee to U.S. Department of Energy and its contractors, in paper, from:

\author{
U.S. Department of Energy \\ Office of Scientific and Technical Information \\ P.O. Box 62 \\ Oak Ridge, TN 37831-0062 \\ OSTI http://www.osti.gov \\ Phone: 865.576.8401 \\ Fax: 865.576.5728 \\ Email: reports@osti.gov
}

Available for sale to the public, in paper, from:

\author{
U.S. Department of Commerce \\ National Technical Information Service \\ 5301 Shawnee Road \\ Alexandria, VA 22312 \\ NTIS http://www.ntis.gov \\ Phone: 800.553 .6847 or 703.605 .6000 \\ Fax: 703.605.6900 \\ Email: orders@ntis.gov
}




\section{Cooperative Research and Development Final Report}

In accordance with Requirements set forth in Article XI, A(3) of the CRADA document, this document is the final CRADA report, including a list of Subject Inventions, to be forwarded to the Office of Science and Technical Information as part of the commitment to the public to demonstrate results of federally funded research.

Parties to the Agreement: $\quad$ Virent, Inc.

CRADA Number: $\quad$ CRD-12-462

CRADA Title: $\quad$ Cellulosic Biomass Sugars to Advantage Jet Fuel: Catalytic Conversion of Corn Stover to Energy Dense, Low Freeze Point Paraffins and Naphthenes

Joint Work Statement Funding Table Showing DOE Commitment:

\begin{tabular}{|l|r|}
\hline Estimated Costs & NREL Shared Resources \\
\hline Year 1 & $\$ 1,439,315.00$ \\
\hline Year 2 & $\$ 1,439,315.00$ \\
\hline Year 3 & $\$ 1,439,315.00$ \\
\hline \multicolumn{1}{|c|}{ TOTALS } & $\$ 4,317,945.00$ \\
\hline
\end{tabular}

\section{Abstract of CRADA Work:}

NREL will provide scientific and engineering support to Virent Energy Systems in three technical areas: Process Development/Biomass Deconstruction; Catalyst Fundamentals; and Technoeconomic Analysis. The overarching objective of this project is to develop the first fully integrated process that can convert a lignocellulosic feedstock (e.g., corn stover) efficiently and cost effectively to a mix of hydrocarbons ideally suited for blending into jet fuel. The proposed project will investigate the integration of Virent Energy System's novel aqueous phase reforming (APR) catalytic conversion technology (BioForming®) with deconstruction technologies being investigated by NREL at the 1-500L scale. Corn stover was chosen as a representative large volume, sustainable feedstock.

\section{Summary of Research Results:}

A large majority of the work conducted by NREL for the CRADA was in the "Process Development/ Biomass Deconstruction" area. This involved the development of biomass deconstruction processes on a corn stover feedstock that produced hydrolysate streams that were compatible with and optimized for the Virent catalytic upgrading process to produce an advantage jet fuel product using soluble sugars and other soluble carbon compounds produced by the deconstruction process. NREL performed bench-scale and pilot-scale R\&D to develop the biomass deconstruction processes and routinely supplied the resulting biomass hydrolysates to Virent, who utilized these hydrolysates in its catalytic upgrading process. These efforts were highlight in three major process validation campaigns that were conducted in the beginning, middle, and end of the project. These campaigns served to document key process performance results on the biomass deconstruction process, in addition to generating large volumes of hydrolysates that were used in the catalytic upgrading portion of the validation campaigns that was performed by Virent. 
The activities of the Catalyst Fundamentals area centered around i) understanding the structures of fresh, active catalysts, ii) identifying changes to the catalyst structure that occur during exposure to process conditions and correlating the structure changes with activity changes, and iii) fundamental studies to understand how/why the catalyst changes during use, which can be used to guide the design of more stable catalysts and/or process operating conditions. A variety of analytical and characterization techniques were employed, with the results provided to Virent to help guide catalyst development and optimization.

Work in the Technoeconomic Analysis area was conducted in direct collaboration with Virent and utilized the performance data from biomass deconstruction (NREL) and catalytic upgrading (Virent) in technoeconomic models to measure process improvement progress. NREL's activities in this area were primarily focused on the biomass deconstruction portion of the process, but NREL also interacted with Virent to help integrate the biomass deconstruction and technoeconomic aspects of the technoeconomic analysis models.

\section{Subject Inventions Listing:}

None.

\section{Report Date:}

June 4, 2015

\section{Responsible Technical Contact at Alliance/NREL:}

Rick Elander

Name and email address of POC at company:

Randy Cortright, Randy_Cortright@virent.com

This document contains NO confidential, protectable, or proprietary information. 